\title{
HET VREUGDEVOLLE RIJK VAN HET SPEL EN VAN DE SCHIJN* \\ Over de actualiteit van 'Het Schone' bij Schiller
}

\author{
Hans-Ulrich Lessing
}

“...weil es die Schönheit ist, durch welche man zu der Freyheit wandert".

\section{Inleiding}

De tweehonderdste verjaardag van het overlijden van Friedrich Schiller in het jaar 2005 gaf aanleiding tot heel wat culturele manifestaties. Schiller heeft een indrukwekkend rijk en veelzijdig oeuvre nagelaten: naast drama's, gedichten, verhalen, vertalingen en historische studies publiceerde hij ook een groot aantal filosofisch-esthetische teksten. Zijn voornaamste filosofische werken zijn de Briefe über die ästhetische Erziehung des Menschen (Brieven over de esthetische opvoeding van de mens'. Eduard Spranger bestempelde het als één van de moeilijkste werken uit de Duitse filosofie. In wat volgt, wil ik de kerngedachten van deze moeilijk toegankelijke, complexe verhandeling, die rijk aan gedachten is en veel veronderstelt, op een eenvoudige wijze voorstellen. Ik houd mezelf daarbij aan de tekst zelf en concentreer me op het wezenlijke. De filosofische achtergrond van Schillers ingewikkelde speculatieve onderscheidingen en argumenten, met name de idealistische filosofie van Kant en Fichte, laat ik buiten beschouwing.

\section{Biografische en werkhistorische plaats van de 'Briefe'.}

In de jaren 1791 tot 1795 heeft Schiller zich intensief met filosofische en in het bijzonder met esthetische kwesties ingelaten. Hieraan gingen indringende historische studies vooraf (vanaf 1786); overigens nam Schiller in deze periode ook een onbezoldigd hoogleraarschap in de geschiedenis te Jena waar. Op 15.12. 1788 verkreeg hij deze leerstoel; de titel van zijn inaugurale lezing luidde: 'Wat betekent algemene geschiedenis en met welk doel bestudeert men ze?' Schillers voornaamste historische studie is een geschiedenis van de secessie der Nederlanden. Hij begon met het schrijven van dit werk, dat hem zijn hoogleraarschap bezorgde, in het jaar 1786. Het eerste deel verscheen in oktober 1788. In januari 1790 begint Schiller aan de bronnenstudie voor de geschiedenis van de dertigjarige oorlog, zijn tweede omvangrijke historische studie. Tegelijkertijd groeit zijn interesse voor esthetische vraagstukken, in het bijzonder voor de theorie van de tragedie. 
Het eerste deel van de geschiedenis van de dertigjarige oorlog is in de herfst van 1790 klaar en verschijnt in de Historischen Kalender für Damen auf das Jahr 1791. In februari 1791 onderneemt Schiller, na een zware ziekte en nadat hij de schets van zijn Wallenstein-drama op papier zette, een grondige studie van Kants werk, in het bijzonder van diens Kritik der Urteilskraft. Op initiatief van de Deense auteur Jens Baggesen ontvangt Schiller in december 1791 door de tussenkomst van de erfprins Friedrich Christian von SchleswigHolstein-Sonderburg-Augustenburg en diens minister van financiën, graaf Ernst Heinrich von Schimmelmann, een lijfrente van drie jaar ten belope van 3000 Taler. Hierdoor is hij een tijdlang bevrijd van de bedrukkende geldzorgen en kan hij zich nu ten volle wijden aan zijn filosofisch-esthetische beschouwingen en zijn studie van Kant verder zetten.

In de herfst van 1792 beëindigt Schiller zijn geschiedenis van de dertigjarige oorlog; ze verschijnt in de Historischen Kalender für Damen auf das Jahr 1793. In het wintersemester 1792-93 houdt Schiller college over esthetica. Hij overweegt, om een kunstfilosofische dialoog te schrijven met de titel: Kallias oder über das Schöne. In januari en februari 1793 maakt hij aan zijn vriend Körner (in de zogenaamde Kallias-brieven) gewag van zijn kunstfilosofische overpeinzingen. In het zomersemester van 1793 zet hij zijn college over esthetica verder; het wordt overigens zijn laatste. Daarnaast schrijft hij nog twee esthetische verhandelingen: Über Anmut und Würde en Vom Erhabenen. Tevens begint hij aan de briefwisseling met Prins von Augustenburg, de Augustenburger-Briefe, die over de filosofie van het Schone handelen. Deze correspondentie vormt het prille begin en tegelijk de meest oorspronkelijke redactie van de Briefe über die ästhetische Erziehung des Menschen. Midden 1794 onderneemt Schiller een grondiger Kantstudie. In deze periode vangt tevens zijn vriendschap met Goethe aan.

In september 1794 begint Schiller met zijn Briefe. Eerder, in februari van hetzelfde jaar, waren de Augustenburger-Briefe voor het overgrote gedeelte bij de brand van het koninklijk paleis Christiansborg te Kopenhagen in vlammen opgegaan. In februari 1795 verschijnt voor het eerst Horen, Schillers ambitieus project voor een tijdschriftenreeks. In de eerste nummers (1,2 en 6) publiceert hij de Briefe. In de lente van 1795 wijst hij het aanbod van een leerstoel voor filosofie in Tübingen af. Op het einde van dat jaar komen er nog enkele andere esthetische verhandelingen: Uber die Gefahr ästhetischer Sitten, Von der notwendigen Grenze des Schönen, alsook Uber das Schöne, (als een deel van Über naive und sentimentalische Dichtung). Verder volgen nog de teksten: Der sentimentale Dichter en Beschluss der Abhandlung über naive und sentimentale Dichtung - wellicht, naast de Briefe, Schillers meest bekende esthetisch geschrift; deze teksten verschijnen in de Horen in 1795-96.

Nadat hij in januari en februari 1796, in nauw contact met Goethe, de Xenien schreef, wijdt Schiller zich in de lente van hetzelfde jaar opnieuw aan zijn plannen voor een drama, zijn Wallenstein. 


\section{Schillers project van een 'esthetische opvoeding'}

De verhandeling Über die ästhetische Erziehung des Menschen omvat zevenentwintig brieven en kunnen we - grofweg - in drie delen opdelen: de brieven 1-9 vormen een analyse en kritiek van zijn tijd, in het bijzonder van de vervreemdingsverschijnselen, die met de moderniteit gepaard gaan; de brieven 10-16 vormen het theoretisch-filosofische hart van de tekst. Hier biedt Schiller een analyse van de menselijke aandrift en ontwikkelt hij zijn concept van schoonheid. De brieven 17-27 bereiken een hoogtepunt met de schets van een utopische esthetische staat.

\section{De brieven 1-9}

In deze brieven wil Schiller op de eerste plaats "resultaten van mijn opzoekingen over het Schone en de Kunst" aan graaf von Augustenburg voorleggen. Hij schrijft over een onderwerp, het schone en de kunst, "dat met het beste deel van ons geluk nauw verbonden is en niet ver afstaat van de morele adel van de menselijke natuur" (Brief 1). De gedachten, die hij wil voorstellen - en hier maakt Schiller meteen duidelijk, dat hij zich op de eerste plaats voor iemand houdt, die zelf denkt - zijn "eerder ontstaan uit de eenvormige omgang met mezelf dan uit een rijke wereldervaring of uit lectuur". Niettemin berusten zijn beschouwingen, zo voegt hij eraan toe, "grotendeels op de principes van Kant".

Ofschoon eenieder met de betekenis van dit studieobject vertrouwd kan zijn, laat Schiller zich met de tegenwerping in, dat een esthetisch traktaat misschien toch niet zo actueel is: zijn de morele en politieke gebeurtenissen, met name de Franse revolutie en haar gevolgen voor Duitsland, niet veel belangrijker? Dient men niet op de eerste plaats hieraan een filosofische beschouwing te wijden? Schiller zelf stelt zich de retorische vraag, of het niet een nijpender aangelegenheid is, "om zich met het meest volmaakte van alle kunstwerken, namelijk met de verwezenlijking van een waarachtige politieke vrijheid in te laten?" (Brief 2).

Schillers diagnose luidt, dat de kunst niet aan de orde van de dag is. De "kunst van het ideaal" heeft zelfs nood aan een afstand van de politieke en economische realiteit. Want "de kunst is een dochter van de vrijheid én van de noodwendigheid van de geest; ze wenst van de nooddurft van de materie geen voorschriften te ontvangen". Tegenwoordig, zo schrijft Schiller, "heerst evenwel behoefte en buigt de mensheid onder het juk van haar tyrannie". "Het voornaamste drogbeeld van onze tijd is utiliteit; alle krachten worden haar ten dienste gesteld, alle talenten ertoe genoopt, haar te huldigen." De "geestelijke verdienste van de kunst" is "van geen tel"; het ontbreekt haar aan impact; ze keert de rug naar het publieke domein, "naar de lawaaierige marktplaats, die onze eeuw geworden is". 
Allen, zowel publiek als filosofen, kijken "vol verwachting naar het politieke schouwspel, waar thans, zo denkt men, over het grote lot van de mensheid wordt beslist". Geven de zuiver esthetische overpeinzingen, die Schiller wil voorleggen, in dit geval geen uitdrukking aan "een te misprijzen onverschilligheid voor het gemeenschappelijk welzijn"? Schillers antwoord is eenvoudig én duidelijk: zijn beslissing, om "de schoonheid te laten voorafgaan aan de vrijheid" is hem niet alleen maar door een persoonlijke neiging ingegeven, maar door "principes", die filosofisch onderbouwd kunnen worden. Hij wil namelijk aantonen, dat zijn studie van het Schone en van de Kunst niet de vrucht is van een belangstelling, die veraf staat van de interesses van de gewone man, geen vlucht uit de wereld is, en dat men, om het nijpende politieke vraagstuk te kunnen oplossen, "de weg van het esthetische moet kiezen", omdat - en dit is zijn voornaamste stelling - "men via de schoonheid naar de vrijheid wandelt".

Om deze gewaagde stelling te onderbouwen, kiest Schiller, zo zou men kunnen stellen, de weg van een politieke antropologie. In wezen houdt deze voor, dat de redelijke, mondige en dus verlichte mens een politiek doel voor ogen staat, dat van het grootste belang is: hij wijdt zich aan de omvorming van de "noodstand of de natuurstaat", die ontspringt aan de "bestemming van de menselijke natuur", tot een "morele staat", die op de wetmatigheid van de rede berust. "Natuurstaat" noemt Schiller elk "politiek lichaam (...), waarvan de inrichting niet uit wetmatigheden, maar oorspronkelijk uit krachten voortvloeit" (Brief 3). Derhalve is de natuurstaat, welke de "nood louter en alleen volgens natuurwetten" heeft ingesteld - en niet volgens de "wetmatigheden van de rede" -, wanneer hij "voor de rechterstoel van de rede" dient te verschijnen, niet gewettigd. Men heeft er alle reden toe, om deze natuurstaat te hervormen: "het werk van blinde krachten heeft generlei gezag, waarvoor de vrijheid dient te buigen; alles dient zich te onderwerpen aan het hoogste doeleinde, dat de rede opstelt en in de persoonlijkheid van de mens inschrijft".

Deze omwenteling van de staat veronderstelt evenwel een bijzonder type mens of karakter. Het kan daarbij niet gaan om "het natuurlijke karakter van de mens". Deze is namelijk "zelfzuchtig en gewelddadig". Maar ook "het morele karakter" komt niet ter discussie; dit moet dankzij de hervorming van de staat nog het licht zien. Er is dus volgens Schiller "een derde karakter" nodig, dat "zich een weg dient te banen van de heerschappij van louter krachten naar een heerschappij van wetten, zonder daarbij een hinderpaal te vormen voor de ontwikkeling van het morele karakter: het zou dus veeleer een zinnelijk onderpand voor de onzichtbare moraliteit moeten vormen".

Wat gezocht wordt, is dus een karakterideaal - daarover handelt Brief 4 . Het is een dwingende vereiste, "dat de mens, die in de tijd leeft, zich veredelt tot een mens, die de idee koestert". Enkel deze mens kan de hoogdringende "hervorming van de staat naar morele beginselen tot stand brengen en op een duurzame wijze bestendigen". Dit karakter ontbreekt echter in de huidige tijd. 
Weliswaar zijn de uiterlijke voorwaarden voor de hervorming van de staat tot een morele orde bijzonder gunstig. Het ontbreekt evenwel aan de onontbeerlijke innerlijke vereisten:

Het gebouw van de natuurstaat wankelt; zijn fundamenten zijn vermolmd en bezwijken, en de fysieke mogelijkheid dient zich aan, om de wet op de troon te heffen, om eindelijk de mens als 'doel op zich' te eren en de ware vrijheid tot grondslag te maken van elke politieke vereniging. IJdele hoop! Het ontbreekt aan de morele vereiste, en de vrijgevigheid van het ogenblik stuit op een geslacht, dat hiervoor onontvankelijk is (Brief 5).

De huidige mens is, zo luidt Schillers diagnose, ontaard: "de lagere klassen, die de meerderheid vormen", zijn verwilderd; de "meer beschaafde klassen" zijn verzwakt, vertonen een karakteriële armoede, dat wil zeggen: ze zijn verdorven. De "verlichting van het verstand", waarop zo velen hun hoop hadden gevestigd, is in Schillers ogen mislukt: "in haar geheel vertoont ze een zo geringe veredelende invloed op de mentaliteit, dat ze eerder nog het verderf door maximes bestendigt". De cultuur van de Verlichting heeft de mens niet tot vrijheid verholpen. Wel integendeel. "Met elke kracht, die ze in ons ontwikkelt, creëert ze een nieuwe behoefte." Ze bevrijdt ons niet van het materiële. Het resultaat van de Verlichting is een nieuwe of een toegenomen afhankelijkheid. "Het is beangstigend om te zien, hoe de boeien van het fysieke steeds strakker worden aangehaald."

Schillers oordeel over de morele en geestelijke situatie van de tijd is derhalve zeer kritisch. "Men stelt dus vast, dat de tijdsgeest zwalpt tussen datgene, wat verkeerd en wat ruw is, tussen wat onnatuurlijk en wat louter natuur is, tussen bijgeloof en moreel ongeloof. De enige beperking is deze, die door het evenwicht van het slechte wordt opgelegd."

Het positieve tegenbeeld van de moderne mens biedt voor Schiller het klassieke Griekenland. De Griekse mens, die "zich in de echt verbond met alle prikkelende schoonheid van de kunst en alle waardigheid van de wijsheid" (Brief 6), beantwoordt ten volle aan het ideaal van een verfijnd en ontwikkeld mensdom:

Vergeleken met de eenvoud, die de Grieken bezaten en die ons tijdvak zo volkomen vreemd is, moeten we ons niet enkel schamen; we moeten ze liefkozen; ze strekken ons tot voorbeeld. We delen met hen dezelfde voordelen, die ons een troost mogen zijn, als het om het tegennatuurlijke van onze zeden gaat.

Bij de Griekse mens gaat het Schiller voornamelijk om de totaliteit van diens natuur. Deze vormt een harmonisch evenwicht van alle krachten. De zinnen en de geest zijn nog niet gedeeld in twee onderscheiden sferen. De Griekse mens vormt nog een eenheid; de moderne mens daarentegen is verscheurd. 
De oorzaak hiervan is volgens Schiller de moderne cultuur. De ontwikkeling van het moderne bestaan leidt tot een opdeling van de samenleving en een verdeling van de beschikbare arbeid. Hierdoor is "het innerlijke verbond van de menselijke natuur geschonden; een verderfelijke tweestrijd splijt het harmonische geheel van zijn krachten". De moderne mens is "een fragment" geworden; de moderne samenleving is een mechanisme. De Griekse mens daarentegen vormt een volkomen, harmonische eenheid in een organisch staatsbestel. De bijzondere natuur van de Griekse staat bestond hierin, "dat elk individu van een onafhankelijk bestaan genoot en indien nodig zich met het geheel kon verenigen". "In de plaats hiervan is een kunstmatig vervaardigd uurwerk getreden; uit de samenstelling van oneindig vele, maar levenloze delen wordt een mechanisch leven in zijn geheel opgebouwd." De moderne mens "stempelt het mensdom niet meer door zijn natuur; hij is herleid tot een afdruk van zijn bezigheden, van zijn wetenschap". Hij heeft nog slechts een "fragmentarisch aandeel" in het geheel. Deze eenzijdige ontwikkeling van de menselijke krachten heeft een "verbrokkeling" van zijn wezen tot gevolg. Specialisatie, de "gescheiden ontwikkeling van de menselijke krachten", betekent voor de individuen een ontwrichting en verarming; voor de samenleving is ze evenwel een belangrijke verrijking:

Eenzijdigheid in het uitoefenen van krachten voert het individu onvermijdelijk tot dwaling; de soort leidt ze evenwel naar de waarheid. Daardoor, dat we de gehele energie van onze geest in één brandpunt verzamelen, ons gehele wezen in één enkele kracht concentreren, geven we aan deze ene kracht a.h.w. vleugels; op bekwame wijze drijven we ze op tot ver buiten de grenzen, die de natuur haar lijkt te hebben gesteld (Brief 6).

Deze evolutie naar een eenzijdig gevormde, fragmentarische mens is voor Schiller evenwel geen onontkomelijke natuurwet. Want de natuur kan door haar doeleinden ons nimmer beroven van een volkomenheid, "welke ons de rede in haar doeleinden voorschrijft". Derhalve - zo besluit Schiller:

moet het onjuist zijn, dat de uitbouw van individuele krachten noodzakelijkerwijze leidt tot het opofferen van hun totaliteit; anders gezegd: hoezeer ook de natuurlijke wetmatigheid hiernaar moge streven, het hangt van ons af, of we deze totaliteit van onze natuur, die door onze eigen kunstvaardigheid wordt vernietigd, zullen herstellen dankzij een hogere kunst.

Hiermee heeft Schiller de fundamentele stelling van zijn verhandeling en meteen ook het doel van zijn argumentatie uitgesproken: de door onze kunstvaardigheid, dat wil zeggen: door de cultuur, teweeg gebrachte ontwrichting van de mens kan en moet door een hogere kunst worden opgeheven, de verstoorde harmonie door haar worden hersteld. 
De politieke doelstelling van een "omwenteling van de staat", waarvan de noodzaak is onderkend, vereist - en dit is Schillers tweede basisstelling - dat de "splitsing, die zich in het innerlijke van de mens heeft voltrokken", en waarvan de diagnose werd gesteld, opnieuw wordt opgeheven en dat - zo voegt hij eraan toe - "de natuur van de mens sterk genoeg is ontwikkeld, om zelf kunstenares te zijn en aan de politieke schepping van de rede haar realiteit te waarborgen" (Brief 7). Zonder herstel van de gehele, harmonische mens, bestaat er met andere woorden geen kans, om de politieke situatie op een succesvolle en duurzame wijze te wijzigen en een moreel staatsbestel tot stand te brengen.

Hier ontstaat evenwel een cirkelredenering, die Schiller zelf onderkent en als volgt beschrijft:

De theoretische cultuur dient de praktische dichterbij te brengen en toch zou de praktische cultuur de voorwaarde van de theoretische zijn? Elke verbetering van de politieke toestand zou moeten uitgaan van de veredeling van het karakter, maar hoe kan het karakter veredeld worden onder de invloed van een barbaars staatsbestel? (Brief9)

Uit deze impasse leidt ons volgende belangwekkende gedachte van Schiller: "Men zou dus tot dit doel een instrument moeten zoeken, dat de staat ons niet ter beschikking stelt, en de bronnen opsporen, die ondanks het politieke verderf, zuiver en ongeschonden bewaard werden." Dit instrument vindt Schiller in de Schone Kunst; hier ontspringen de bronnen, die hij zoekt, "die zich in hun onsterfelijke patronen ontvouwen".

Voor Schiller zijn kunst en wetenschap - en in dit opzicht is hij een idealist - autonoom, onafhankelijk van elke politieke beïnvloeding:

beide kunnen zich verheugen in een volstrekte immuniteit voor de menselijke willekeur. De politieke wetgever kan hun gebied afsluiten, maar vermag het niet, op dit domein macht uit te oefenen. Hij kan de waarheidslievende verachten, maar de waarheid bestaat. Hij kan de kunstenaar vernederen, maar hij vermag het niet, om de kunst te vervalsen.

De brieven 10-16.

De volgende brieven vormen het centrum van Schillers verhandeling. Hierin ontvouwt hij zijn concept van schoonheid dat niet aan een zuiver theoretische belangstelling beantwoordt. De schoonheid heeft veeleer een morele en een politieke kwaliteit. Haar opdracht bestaat erin, om de mens uit zijn "tweevoudige dwaling", namelijk "ruwheid en zwakte" (Brief 10) te bevrijden en hem naar zijn uiteindelijke bestemming te leiden.

Er stelt zich echter een bijzonder probleem. De historische beschouwing leert ons, dat een hoog ontwikkelde esthetische cultuur van een volk nimmer 
"hand in hand ging met politieke vrijheid en burgerlijke deugdzaamheid". "Waar we ook in het verleden rondkijken, steeds zien we dat smaak en vrijheid elkaar ontvluchten en dat de schoonheid haar heerschappij op de ondergang van de heldhaftige deugd heeft gevestigd." Toch laat Schiller zich door dit resultaat van de ervaring niet afschrikken. "De ervaring" is namelijk niet "de rechterstoel", voor welke men een kwestie als deze kan brengen en beslechten. Want het begrip van de schoonheid, dat Schiller wil ontvouwen, is geen ervaringsbegrip. Het heeft - zo betoogt hij - "een andere bron (...) dan de ervaring, want aan de hand van dit begrip kan worden onderkend, of datgene, wat in de ervaring doorgaans voor schoon wordt gehouden, met recht ook deze naam moge dragen". Schiller wil dus een zogenaamd "transcendentaal" begrip van schoonheid ontwikkelen, een "zuiver redebegrip van schoonheid", dat - zo verklaart hij - "uit geen enkel concreet geval kan worden geput, daarentegen ons oordeel over elk concreet geval tot richtsnoer dient". Zo'n redebegrip van de schoonheid moet "worden opgespoord op de weg van de abstractie en reeds uit de mogelijkheid van de zinnelijk-redelijke natuur zelf afgeleid kunnen worden". De bepaling van een zulkdanig begrip veronderstelt derhalve een speculatieve, niet-empirische analyse van "het zuivere begrip mensheid", dat wil zeggen: van de menselijke natuur, om aan te tonen, dat de schoonheid "een noodzakelijke voorwaarde van de mensheid" is en niet enkel maar een empirisch-toevallige eigenschap.

In deze analyse maakt Schiller het onderscheid tussen "datgene, wat blijft en dat, wat onophoudelijk verandert", dat wil zeggen: tussen de "persoon" van de mens en zijn "toestand" (Brief 11). Dit onderscheid brengt hem tot het postuleren van aan elkaar tegengestelde fundamentele krachten of aandriften in de mens. De eerste aandrift noemt Schiller de "zinnelijke" of "stoffelijke aandrift" (Brief 12). Deze "gaat uit van het fysieke bestaan van de mens of van zijn zinnelijke natuur"; "het is zijn taak, om de mens binnen de grenzen van de tijd te plaatsen en hem tot materie te maken". Deze drift reikt zover "als de eindigheid van de mens". En het is deze drift, "waaraan de gehele verschijning van de mensheid is bevestigd".

De tweede aandrift is de "vormelijke aandrift". Deze "gaat uit van het absolute bestaan van de mens of van zijn redelijke natuur, en streeft ernaar, hem viij te maken, harmonie te brengen in de verscheidenheid van zijn verschijning en bij alle wisseling van zijn toestanden zijn persoon te handhaven en te bevestigen." De vorm-drift dringt, zoals Schiller zegt, aan "op de bevestiging van persoonlijkheid": "hij heft de tijd, de verandering op; hij wil, dat wat werkelijk is, ook noodzakelijk en eeuwig is, en dat het eeuwige en noodzakelijke ook werkelijk is: met andere woorden: hij stuurt aan op waarheid en recht".

Met deze twee aan elkaar tegengestelde fundamentele aandriften: de zinnelijkheid en de redelijkheid, is "het begrip van mensheid" uitputtend behandeld (Brief 13). Een derde fundamentele aandrift, die tussen beide zou bemiddelen, "is zonder meer ondenkbaar". Maar beide staan met elkaar onophoudelijk in "wisselwerking": "zonder vorm geen materie, zonder materie 
geen vorm". Deze wisselwerking is noodzakelijk, omdat, wanneer de ene aandrift op de andere de bovenhand zou behalen, een dramatisch onevenwicht zou ontstaan. "Wordt de zinnelijke aandrift bepalend, dan dicteren de zinnen de wet en onderdrukken ze de persoon." "Zodra de mens alleen maar vorm is, heeft hij geen vorm; en met de toestand is derhalve ook de persoon opgeheven". Voor de mens is daarom een harmonisch evenwicht, een geslaagde verbinding van beide van doorslaggevende betekenis: ze is de "idee van zijn menszijn":

Waar beide eigenschappen zich verenigen, daar zal de mens met de hoogste voldragenheid van zijn bestaan ook de grootste zelfstandigheid en vrijheid verbinden en, in plaats van zich aan de wereld te verliezen, deze veeleer in zich opnemen, met de oneindigheid zijner verschijningen, om hem aan de eenheid van zijn rede te onderwerpen (Brief 13).

In de veronderstelling dat in sommige gevallen zo'n geslaagde verbinding in de mens tot stand zou komen, kan men dan ook een "nieuwe aandrift" aannemen, "die juist omdat de beide andere in hem samenwerken aan elk van hen, afzonderlijk beschouwd, tegengesteld zou zijn". Schiller bestempelt de aandrift, "waarin beide met elkaar verbonden samenwerken", als de spel-drift. Deze drift "zou erop gericht zijn, de tijd in de tijd op te heffen, worden met absoluut zijn, verandering met identiteit te verenigen" (Brief 14).

Deze omschrijving van de speldrift biedt nu aan Schiller de mogelijkheid, om zijn begrip van schoonheid te ontplooien. Dit gebeurt op een enigszins schematische manier. Als "voorwerp van de zinnelijke aandrift" (Brief 15) bestempelt hij op de eerste plaats "het leven in zijn breedste betekenis". Daaronder verstaat men "het gehele materiële bestaan en alles, wat in de zinnen tot tegenwoordigheid komt". Het "voorwerp van de vormelijke aandrift, in een algemeen begrip gevat" is "Gestalt". Hienuit vloeit noodzakelijkerwijze voort, dat "het voorwerp van de spel-drift, voorgesteld in een algemeen schema", als "levende gestalte " kan worden omschreven. En dit begrip is "dienstig", zo schrijft Schiller, "om alle esthetische kwaliteiten van de verschijningen en met één woord om al datgene, wat men in de breedste betekenis Schoonheid noemt, te beschrijven".

Schiller beklemtoont nu, dat door dit begrip, door deze verklaring, "de schoonheid noch tot het gehele gebied van wat leeft wordt uitgebreid, noch tot dit gebied wordt beperkt". Hij geeft hierbij volgende toelichting. "Een marmeren blok, ofschoon hij levenloos is en blijft, kan desalniettemin om die reden tot een levende gestalte worden verheven door de hand van de architect of de beeldhouwer; en de mens, ofschoon hij leeft en een gestalte bezit, is daarom nog bij lange niet een levende gestalte." Wanneer wordt iets een "levende gestalte" en dus schoon? Schiller antwoordt hierop: 
Daartoe hoort, dat zijn gestalte leven en zijn leven gestalte is. Zolang we over zijn gestalte enkel nadenken, is het levenloos, een pure abstractie; zolang we zijn leven alleen maar aanvoelen, is het zonder gestalte, een pure indruk. Pas wanneer zijn vorm in ons aanvoelen leeft, en zijn leven in ons verstand vorm verwerf, is het een levende gestalte, en dit zal telkens het geval zijn, wanneer we het als iets schoon beoordelen. (Brief 15).

Schoonheid is dus, zo zou men kunnen zeggen, doorleefde vorm en tegelijkertijd gevormd, dat wil zeggen: verstandsmatig begrepen leven.

Schoonheid is dus niet het voorwerp van één der beide aandriften, maar "het gemeenschappelijk voorwerp van beide, dat wil zeggen: van de spel-drift".

Men zou kunnen tegenwerpen, dat men, door de schoonheid tot een puur spel te verklaren, "ze vernedert en gelijkstelt met frivole objecten". Schiller verdedigt zich tegen deze opwerping, door te betogen, "dat onder alle toestanden van de mens het precies en uitsluitend het spel is, wat een mens volledig maakt en zijn dubbele natuur in één klap ontplooit". Hierbij denkt Schiller geenszins aan die vormen van spel, die men in het dagelijkse leven beoefent, zoals bijvoorbeeld het kaartspel, en die "meestal op materiële objecten betrekking hebben". Maar "in het werkelijke leven" zouden we ook "vergeefs zoeken" naar de schoonheid, waarvan Schiller gewaagt. Deze schoonheid is namelijk "het ideaal van schoonheid, dat de rede vooropstelt" en hieraan beantwoordt ook een "ideaal van spel-drift, dat de mens in alle vormen van spel voorstaat".

Het gaat dus om het redebegrip van schoonheid, dat Schiller in zijn tekst ontvouwt. En deze rede zegt: "de mens dient met de schoonheid alleen te spelen, en alleen met de schoonheid dient hij te spelen". Want - en wat volgt is één van de meest bekende Schillercitaten - "de mens speelt alleen daar, waar hij in de volle betekenis van het woord mens is, en hij is alleen daar geheel mens, waar hij speelt".

Deze uitspraak lijkt - zoals Schiller overigens toegeeft - voor velen "allicht paradox te zijn". Maar hij "leeft en gedijt" volgens Schiller "in de kunst en in het gevoel van de Grieken, haar grootste meesters" - evenwel met deze beperking "dat zij naar de Olympus verhuisden, wat op aarde had moeten uitgevoerd worden", dat wil zeggen dat zij het ideaal van het spel en daarmee het ideaalschone in een hemels godenrijk verwezenlijkten.

De schoonheid heeft nu, zo Schiller, "twee vormen van werkzaamheid" (Brief 16). Men kan van het schone "tegelijk een ontspannende en een spanning veroorzakende werking verwachten (...): een ontspannende, om zowel de zinnelijke aandrift als de vormelijke binnen hun grenzen te houden; een spanning verwekkende, om beide in hun kracht te bewaren". Het schone vertoont dus een "smeltende" en een "energieke" eigenschap. De werking van de "energieke schoonheid" bestaat erin, om "het gemoed, zowel wat het fysieke als het morele aangaat, onder spanning te brengen en de kracht zijner snelheid op te voeren". 
De werking van de "smeltende schoonheid" is deze, "het gemoed, zowel aangaande het fysieke als het morele, te ontspannen".

\section{De brieven 17-27.}

Nadat Schiller in de brieven 10 tot 16 de "algemene idee van schoonheid uit het begrip van de menselijke natuur als zodanig" heeft afgeleid, neemt hij - grof gezegd - het effect van de schoonheid op de mens onder de loupe. Hij herinnert eraan, dat de volkomenheid van de mens "in de overeenstemmende energie van zijn zinnelijke en geestelijke krachten" bestaat. Deze volkomenheid kan, zoals de rede ons met stelligheid toont, hetzij door "een gebrek aan overeenstemming", hetzij door "een gebrek aan energie" (Brief 17) buiten ons handbereik liggen. De mens bevindt zich dus in zijn beperktheid hetzij in een "toestand van spanning" of van "ontspanning", en dit, "naargelang hetzij de eenzijdige werkzaamheid van individuele krachten de harmonie van zijn wezen verstoort, of de eenheid van zijn natuur berust op een gelijkvormige verzwakking van zowel zijn zinnelijke als geestelijke krachten". Schiller betoogt in wat volgt, dat

beide aan elkaar tegengestelde beperkingen (...) door de schoonheid worden opgeheven, welke in de gespannen mens de harmonie, in de ontspannen mens de energie herstelt en op deze wijze, in overeenstemming met haar natuur, de beperkte toestand naar een absolute terugvoert, derhalve de mens tot een geheel maakt, dat in zichzelf voldragen is (Brief 17).

Men zou dus kunnen aanvoeren, dat volgens Schiller schoonheid een heilzaam middel is voor de onvolkomenheid en beperktheid van de mens, die zijn idee niet vermag te bereiken.

Hiertoe neemt hij het reeds eerder gehanteerde begrip van de smeltende en de energieke schoonheid opnieuw ter hand, waarbij - zo verklaart hij - de smeltende schoonheid een "gespannen gemoed", de energieke schoonheid een "ontspannen gemoed" ter hulp snelt.

Gespannen is de mens enkel, wanneer hij zich onder de dwang van gevoelens, alsook, wanneer hij zich onder de dwang van begrippen bevindt. Elke uitsluitende heerschappij van één der beide fundamentele aandriften betekent een toestand van dwang en geweld; de vrijheid is hem enkel in de samenwerking zijner beide naturen geschonken (Brief 17).

"Gespannen" is dus in Schillers terminologie ieder mens, in wie hetzij de zinnelijkheid, hetzij de rede de overhand heeft. Deze eenzijdigheid in de psychische structuur wordt door de smeltende schoonheid ongedaan gemaakt: "De mens, die eenzijdig door gevoelens wordt beheerst of door de zinnen in spanning wordt gebracht, ontspant zich en bevrijdt zich door vorm; de mens, in 
wie de wetmatigheden eenzijdig heersen en die door zijn geest in spanning wordt gehouden, maakt zich vrij en ontspant zich door de materie".

Om deze tweevoudige opgave te vervullen, dient de smeltende schoonheid twee gestaltes aan te nemen:

Eerst en vooral zal ze, als een vorm in rust, de wildheid van het leven verstillen en de weg banen, die van de gevoelens naar de gedachten leidt; ten tweede zal ze, als een levend beeld, de abstracte vorm toerusten met een zinnelijke kracht, en het begrip terugleiden naar de aanschouwing zoals de wetmatigheid naar het gevoel. De eerste dienst biedt ze aan de natuurmens; de tweede aan de kunstvaardige mens (Brief 17).

Schoonheid kan dus - en hiermee onderbouwt Schiller zijn fundamentele stelling, een middel worden, om "de dubbele spanning, waarvan sprake was, op te heffen". Met andere woorden: "Door de schoonheid wordt de mens der zinnen naar de vorm en het denken geleid; door de schoonheid wordt de mens van de geest naar de materie gebracht en aan de wereld der zinnen teruggegeven" (Brief 18).

Schiller betoogt dus, dat er geen andere weg bestaat, om de mens der zinnen tot rede te brengen, "dan hem allereerst esthetisch te maken". De schoonheid, die "de esthetische gemoedsstemming" in ons wekt, biedt volgens Schiller de mogelijkheid, "opdat er voor de mens der zinnen een zuivere vorm als zodanig zou bestaan", met andere woorden, dat hij ontvankelijk wordt voor waarheid en plicht, derhalve voor de aanspraken van rede en moraal. Daarom ook kan Schiller betogen:

Door de esthetische gemoedsstemming wordt de zelfwerkzaamheid van de rede alreeds op het gebied van het zinnelijke gewekt, de macht van het gevoel reeds binnen zijn eigen grenzen doorbroken en de fysische mens zodanig veredeld, dat de geestelijke mens zich in hem enkel nog dient te ontplooien volgens de wetmatigheid van de vrijheid (Brief 23).

Schiller besluit hieruit tot volgende gevolgtrekking, die voor hem van groot belang is: "Het behoort tot de wezenlijke opdracht van de cultuur, om de mens alreeds in zijn louter fysieke leven aan de vorm te onderwerpen en hem, zover het rijk van de schoonheid zich moge uitstrekken, esthetisch te maken, omdat alleen uit de esthetische, en niet uit de fysische toestand, de morele zich kan ontwikkelen." "Een esthetische cultuur" is van node, "een opvoeding tot smaak en tot schoonheid", "met het doel, het geheel van onze zinnelijke en geestelijke krachten zo te vormen, dat hun grootst mogelijke harmonie in het bereik is" (Brief 20, voetnoot). 
In dit verband beklemtoont Schiller, dat het Schone en de door het Schone gewekte stemming geen bijdrage kunnen leveren tot de kennis en tot de verheffing van de gezindheden:

de schoonheid heeft geen enkel resultaat, noch voor het verstand, noch voor de wil; ze oefent geen enkele intellectuele of morele doelmatigheid uit; ze vindt geen enkele waarheid; ze helpt ons niet, welke plicht dan ook te vervullen; ze is, met één woord, evenmin geschikt, om het karakter te grondvesten dan wel om een helder hoofd te bekomen (Brief 21).

De esthetische cultuur kan er alleen toe bijdragen, "dat het de mens thans van nature uit mogelijk wordt, om van zichzelf te maken, wat hij wil - dat hem opnieuw de volle vrijheid ter beschikking wordt gesteld, om te zijn, wat hij moet zijn". Door de schoonheidservaring wordt dus in de mens "de eenzijdige dwang van de natuur bij het voelen" en "de eenzijdige wetmatigheid van de rede bij het denken" gebroken en hem zijn vrijheid teruggeschonken. Dit vermogen, dat in de esthetische stemming aan de mens wordt teruggegeven, houdt Schiller "voor het hoogste aller geschenken, voor het geschenk van de mensheid". Het geeft hem ook het recht, om de schoonheid "onze tweede schepper" te noemen.

Uit zijn esthetische overwegingen distilleert Schiller enkele gevolgtrekkingen van geschiedfilosofische aard. Hij onderscheidt in de menselijke ontwikkeling "drie welonderscheiden momenten of fasen, (...) die zowel het individu als de soort noodzakelijkerwijze en in een welbepaalde volgorde doorlopen, willen ze hun bestemming in haar volle omvang vervullen" (Brief 24). Deze drie fasen zijn de fysieke, esthetische en morele fase: "De mens in zijn fysieke toestand ondergaat alleen de macht van de natuur; hij maakt zich hiervan vrij in de esthetische toestand en hij beheerst ze in de morele". Deze fasen zijn overigens niet uit de ervaring afgeleid, maar zijn "louter de vrucht der gedachten".

In de fysieke en "dierlijke toestand", die Schiller ook "natuurtoestand" noemt, gaat de mens in zijn geheel op in de natuur. Eerst in de esthetische toestand doet zich een "wereld" aan hem voor, aangezien hij zich nu kan onderscheiden van zijn omwereld. Door de wereld "buiten zich te plaatsen of te beschouwen, zondert hij zijn persoonlijkheid ervan af; hem verschijnt een wereld, omdat hij heeft opgehouden, zich ermee te vereenzelvigen" (Brief 25). De beschouwing of reflectie bevrijdt hem van de macht van de natuur; van een "slaaf der natuur" wordt hij tot de "wetgever ervan", "zodra ze het voorwerp van zijn denken geworden is".

De "esthetische gemoedsstemming" (Brief 26) maakt dus het ontstaan van de vrijheid mogelijk, en kan derhalve zelf "geen morele oorsprong hebben", 
maar deze stemming moet "een geschenk van de natuur" zijn. Ze kan zich alleen ontwikkelen onder welbepaalde ruimtelijke voorwaarden en vormen van klimaat:

\begin{abstract}
Waar een lichte ether de zinnen de toegang schenkt tot welhaast iedere zachte aanraking, en een energieke warmte straalt doorheen een rijkelijk toebedeelde stof, aldaar, in die heuglijke omstandigheid en in deze gezegende zone, waar enkel de daad tot het genot en enkel het genot tot de daad voert, waar uit het leven zelf de heilige orde oprijst, (...) enkel op deze plaats kunnen zinnen en geest, de ontvangende en de vormende kracht, in een fortuinlijke gelijkmatigheid zich ontvouwen, welke de ziel van de schoonheid en de voorwaarde zelf van het menszijn is.
\end{abstract}

Het ware begin van de mens is, zo Schiller, het ogenblik, waarop hij aan de "slavernij van de dierlijke staat" ontkomt en "de vreugde van de schijn leert kennen, de neiging tot sierlijkheid en tot het spel" vertoont, kortom, het moment, waarop de (esthetische) speldrift gewekt wordt.

De esthetische speldrift en de schoonheid bevrijden de mens en vestigen het rijk van de vrijheid: "Midden het schrikbarende rijk van de krachten en midden het rijk der wetmatigheden bouwt de esthetische scheppingsdrang ongemerkt een derde, vreugdevol rijk van het spel en de schijn, waarin hij de mens uit de boeien van alle verhoudingen bevrijdt en hem ontbindt uit alles, wat voor hem dwang betekent, zowel wat het fysieke als het morele betreft." De basisstelregel van dit esthetische rijk is: "vrijheid door vrijheid schenken" (Brief27).

Het Schone bezit een socialiserende werkdadigheid; het verleent de mens een "sociaal karakter", want smaak alleen brengt "harmonie in de samenleving, omdat hij in het individu harmonie sticht". Buitendien draagt het Schone bij tot het menselijke geluk. Niet zonder enige bevlogenheid schrijft Schiller hierover: "Alleen de schoonheid maakt de wereld gelukkig, elk wezen vergeet zijn beperkingen, zolang het de tover ervan ervaart."

In dit "rijk van de esthetische schijn" bestaan geen privileges en is er geen dictatuur: "Dit rijk strekt zich opwaarts uit tot aan het punt, waar de rede met onbeperkte noodwendigheid heerst, en de materie ophoudt te bestaan; het strekt zich neerwaarts uit tot aan het punt, waar de natuurlijke aandrift met blinde noodwendigheid heerst en de vorm nog geen begin heeft; ja, zelfs tot aan deze uiterste grenzen, waar hem zijn wetgevende macht ontnomen is, laat de smaak zich de macht niet ontfutselen, om zich door te zetten." In dit rijk wordt dus, zo stelt Schiller, "het ideaal van de gelijkheid vervuld, dat de dweper zo graag in haar wezen verwerkelijkt zou willen zien".

Maar is deze "staat van de schone schijn", zo vraagt Schiller zich af, enkel een utopie of bestaat hij werkelijk, - en waar kunnen we hem dan vinden? Het antwoord, dat hij op deze vraag geeft, is, zo meen ik, na meer dan tweehonderd jaar nog steeds actueel: 
Hij bestaat in het verlangen van elke fijnbesnaarde ziel; men zou hem daadwerkelijk kunnen aantreffen in enkele zeldzame en uitgelezen kringen, zoals dit ook voor de zuivere kerkgemeenschap en de zuivere republiek het geval is: hier moge niet slaafse nabootsing van vreemde zeden, maar eigen schone natuur de gedragingen besturen; hier schrijdt de mens doorheen de meest verwikkelde verhoudingen met gedurfde eenvoud en rustige onschuld en hoeft hij niet de vrijheid van anderen te krenken, om de eigen vrijheid te bevestigen, noch zijn waardigheid weg te gooien, om de beminnelijkheid van zijn charme te tonen (Brief 27).

(Vertaling: Guy van Kerckhoven)

\section{Noten}

*Tekst van een lezing voor het Studium Generale van het Hoger Architectuurinstituut Sint-Lucas te Gent op 24 mei 2006.

1. Van Über die ästhetische Erziehung des Menschen bestaan meerdere uitgaven; van de Nederlandse vertaling door Aart J. Leemhuis (Kok Agora, 1994) heb ik uitzonderlijk gebruik gemaakt (noot van de vertaler). 